\title{
Popular Participation in Legislative Law-Making under the New Democratic Dispensation in Kenya
}

\author{
Dr John Mukuna \\ Senior Lecturer, Botswana Accountancy College \\ Email: johnm@bac.ac.bw \\ Professor Melvin LM Mbao \\ Executive Dean and Professor of Public Law and Legal Philosophy, \\ North West University, South Africa \\ Email:Melvin.Mbao@nwu.ac.za
}

\section{Doi:10.5901/mjss.2014.v5n20p438}

\section{Abstract}

This article examines the extent of entrenchment of the ideal of participation of the people of Kenya in legislative law-making process under the new democratic dispensation ushered by the 2010 Constitution. In terms of law-making by Parliament and County Assemblies, the 2010 Constitution is a clear departure from the 1963 Constitution which exclusively vested law-making in peoples' representatives. Under the 2010 Constitution, direct participation of the people in law-making and political governance generally is one of the cardinal democratic ideals of the new dispensation. This shift was prompted by decades of usurpation of the role of Parliament by the Executive such that the legislature became a key pillar in the enforcement of authoritarianism in the country. The new trajectory was intended by the drafters of the Constitution to enable the people of Kenya to play a central role in political governance and legislative law-making in particular. This article examines the operationalization of the ideal of popular participation in the legislative or statutory business of Parliament and of the County Assemblies. It argues that notwithstanding clear constitutional provisions for popular inclusion in law-making by these institutions, their law-making processes have not in any meaningful way engaged the people. Their approach has therefore not significantly changed the modus operadi of law-making which dents the road towards the enrichment of the country's democracy. There is therefore compelling need for the law to be reformed so as to fully embrace the voice of the people in lawmaking in Parliament and in the County Assemblies.

Keywords: Constitution, popular participation, democracy, legislature, devolution.

\section{Introduction}

The promulgation of the 2010 Constitution of Kenya brought to a close about two decades of agitation for democratic reforms to the country's independence (1963) Constitution. The 1963 Constitution went through major mutilations necessitated by amendments intended to entrench an all power presidential system, initiatives which culminated in making Kenya a de jure one-party state. Further, the executive took over the country's legislative branch thus destroying the doctrine of separation of powers which is a key pillar of democratic governance.

It is for this reason that the article argues that a central feature of the philosophy underpinning the 2010 Constitution of Kenya is a shift from a pure representative political system to one in which the people would become useful actors in governance, and law making in particular, after the periodic elections are over. One of the means for achieving this aim is by the involvement of the people in law making process. The article examines the new approach from two perspectives namely, inclusion of representatives of the various marginalised groups as members of the Senate and National Assembly (both constituting 'Parliament'). Secondly, the Constitution makes provision for people's direct participation in law making. The article first makes some conceptual observations of the concept of popular participation after which the Kenyan dynamics of this noble ideal are interrogated. The aim of this enquiry is to answer the question whether the new approach of law-making in Kenya is contributing significantly to the country's democratic growth or, as under the old order, the people of Kenya largely continue to be under the siege of the country's political machinery in the country's law-making initiatives. 


\section{Some Observations on the Concept of Popular Participation}

Contemporary discourses on democracy and human rights acknowledge that explicit or tacit involvement of the people in the management of the political institutions of their country is an integral element of good governance. ${ }^{1}$ Further, involvement of the people in public affairs may enhance the people's propensity for them to willingly support the state. ${ }^{2}$ However, there is no consensus on the execution of popular involvement in political affairs. In modern times, the importance of popular participation is derived from key international instruments. These instruments illuminate our discussion because of their relevance under Kenya's new constitutional order. Article 2(5) of the 2010 Constitution provides, in a peremptory language, that "the general rules of international law shall form part of the law of Kenya."

Key among the international instruments is the Universal Declaration of Human Rights (UDHR), the International Covenant on Civil and Political Rights (ICCPR) and the African Union Constitutive Act (AUCA). Participation of the people in the political process is, in terms of Article 21(1) of the UDHR, either direct or indirect, the latter involving the election of representatives to represent a particular electorate. The right enshrined in the above provision is also captured in the ICCPR. ${ }^{3}$ Article 25 of the ICCPR provides that the right to vote at genuine, periodic elections and "to take part in the conduct of public affairs, directly or through freely chosen representatives should be enjoyed without unreasonable restrictions."The AU through the AUCA states one of the objectives of the AU as "to promote democratic principles and institutions, popular participation and good governance."4

One of the foremost instrument in Africa which embraces popular participation from a broader governance perspective is the ACHPR. Article 13 states that:

"1. Every citizen has the right to participate freely in the government of his country either directly or through freely chosen representatives in accordance with the provisions of the law.

\section{Every citizen shall have the right of equal access to the public service of his country.}

\section{Every individual shall have the right of access to public property and services in strict equality of all persons before} the law."

The model of democracy in the AUCA also constitutes one of the elements of the theme of human rights, democracy and good governance of the UN's Millennium Development Goals (MDGs). ${ }^{5}$ In 2000, 186 members of the UN resolved to address poverty and governance issues by among others "to work collectively for more inclusive political

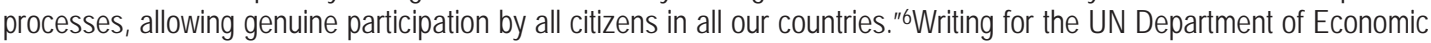
and Social Affairs as regards the road to the achievement of MDGs, Osmani argues that "effective participation by all stakeholders, especially at local level of government, has come to be viewed as a necessary condition for promoting good governance."7

As Osmani has observed, people's participation in governance processes combats deficiencies in governance in addition to its intrinsic benefit because people would be exercising one of their basic freedoms. ${ }^{8}$ Although elections are a positive democratic exercise, he observes that one of the main problems is the long time lag between one election and the next, which can be ameliorated by the representatives being required to explain to the people in meetings what it is, for instance, they have done with the resources entrusted to them. ${ }^{9}$ People's participation also enhances empowerment and social capital which are mutually reinforcing..$^{10}$

From an African perspective, the clearest indication that the $\mathrm{AU}$ is committed to the virtue of popular participation enshrined in the AU Constitutive Act is the entering into force of the African Charter on Democracy, Elections and Governance ("the Charter"). Article 2(10) provides that one of the objectives of the Charter is the promotion and the establishment of conditions which would foster citizen participation in the management of public affairs. This approach is

${ }_{1} \mathrm{C}$ Ochoa "Participatory Democracy and Law Formation" 5 (2008) 15 Indiana Journal of Global Legal Studies 5-18 at 7; Also see, M Mbao and G Komboni "Promotion of good governance and combating corruption and maladministration: the case of Botswana"12(1) (2008) Journal of Law, Democracy \& Development $49-71$ at 50.

2 A Birch, The concepts and theories of modern democracy $3 r d$ ed (2007) at 145.

3 International Covenant on Civil and Political Rights, G.A. res. 2200A (XXI), 21 U.N. GAOR SUPP. (No.16) at 52, U. N. Doc. A/6316 (1966), 999 U.N.T.S. 171, entered into force Mar. 23, 1976, http://www1.umn.edu/humanrts/instree/b3ccpr.htm(accessed 12 June 2013).

${ }_{4}$ Constitutive Act of the African Union, http://www.africa-union.org/root/au/aboutau/constitutive_act_en.htm, (accessed 29 July 2013).

5 United Nations General Assembly, United Nations Millenium Declaration A/RES/55/2, http://www.un.org/milleniumgoals (accessed 12 February 2013).

6 UN Millenium Development Goals (fn 11 above) at 7.

7 S Osmani, "Participatory governance: an overview and evidence," United Nations Department of Economic and Social Affairs, New York, 2008 at 1. Available at http://www.unpan1.un.org/intradoc/groups/public/.../un/unpan028359.pdf(accessed 12 December 2012).

8 Osmani lbid at 1.

9 Osmani lbid at 6.

10 Osmani Ibid at 7 
a departure from the traditional notion of popular participation being the holding of regular elections, recognition that, it is argued, effective participation can only be achieved when the people are directly involved in the affairs of their State. In particular, Articles 29(3) and 31(2) of the Charter require State Parties to create suitable conditions for effective participation of women and social groups with special needs in democracy and developmental processes.

An indirect democratic system is a pure representative system is 'vote-centric' in which the people's role in political governance does not go beyond the polling booth. In this system, the representatives exercise delegated authority with the hope that their "wisdom may best discern the true interest of their country, and whose patriotism and love of justice will be least likely to sacrifice it to temporary or partial considerations." ${ }^{11}$ As the citizen has no other role to play until the next elections, representative democracy therefore becomes what Quant calls' procedural democracy' which is characterised by regular elections and representatives bodies with no space for direct will of the people. ${ }^{12}$

Regular elections remind the representatives of their fiduciary position and on "their dependence on the people."13 However, although elections are a positive democratic process, one of the main weaknesses is the long time lag between one election and the next. Secondly, representative system in many African countries has innumerable challenges which have rendered the credibility of the process questionable. For instance, there is a general unawareness among Africans of who their political representatives are; the legal limitations of presidential tenure and how constitutional rights of a country can be enforced. ${ }^{14}$

While elections are intended to afford the citizens through their representatives a voice in their government, the polling booth device has failed the people as many of them believe that their demands are not addressed through the representative process. ${ }^{15}$ Undoubtedly, representatives of the people "are not necessarily representative of the people." 16 Representative democracy becomes more of a mockery if elections are not credible such that they do not manifest the will of the voters. ${ }^{17}$ Deficiencies of electoral or procedural democracy are compounded by the executive's grip on the people's representatives. As Simutanyi has argued, the executive is in control of the purse and further, the political party system almost ensures that the people's representatives do not oppose instructions of their sponsors, the political parties as they would face severe sanctions by the party. ${ }^{18}$

A deeper form of participation and what we argue embraces pragmatism in the never ending strive for the enrichment of democracy is direct or deliberative democracy. According to Birch, the system extends beyond electing representatives to include playing an active role in the affairs of the government. ${ }^{19}$ In Africa, this form of participation of the people is probably nowhere evident and entrenched as in South Africa. This approach has prompted some American scholars to suggest that the South African Constitution, and we add its jurisprudence on popular inclusion, should be a role model for the United States of America. ${ }^{20}$ The system seems central to the African concept of Ubuntu which has become a key driver of South Africa's jurisprudence of participatory democracy under the constitutional revolution in that country. ${ }^{21}$

In the 'talk-centric' model, the people debate about governance affairs which reinforce participatory democracy and civic engagement. ${ }^{22}$ It is on this premise, and given the challenges of electoral democracy in Africa and Kenya in particular, that direct participation of the people is examined in this article. The hope is that this approach would add colour and legitimacy to representative democracy thus providing a formidable coalition in support of democracy. The next part of this article investigates Kenya's law-making experience under the independence (1963) Constitution which was based on a pure representative political system. It is on this foundation that our examination of law-making under the new (2010) constitutional dispensation is anchored.

\footnotetext{
11 J Madison, The Federalist No. 10: "The utility of the union as a safeguard against domestic faction and insurrection," http://www.constitution.org/fed/federal10htm at 4, (accessed 8 June 2013).

12 M Quandt, "In defence of participatory democracy," http://www.nicanet.org/wp-content/.../158-/participatorydemocracy-pdf (accessed 9 February 2013).

$13 \mathrm{~J}$ Madison, The Federalist No. 57: "The alleged tendency of the new plan to elevate the few at the expense of the many considered in connection with representation," at 2 www.constitution.org/fed/federa57.htm(accesed 10 March 2013).

14 Afro-barometer Network: Working Paper No.16, "Citizens and the state in Africa: New results from Afro-barometer round 3," 2005-2006, http://www.afrobarometer.org page 10 (accessed 12 February 2013).

15 Afro-barometer (fn 13 above) at 10.

$16 \mathrm{~J}$ Hatchard, M Ndulo \& P Slinn, Comparative constitutionalism and good governance in the commonwealth: An Eastern and Southern African perspective (2004) at 124.

17 Afro-barometer (fn 13 above) at 14.

18 N Simutanyi, "Parties in parliament: The relationship between members of parliament and their parties in Zambia," EISA Occasional Paper No. 36 September 2005, http://www.eisa.org.za/PDF/DF/OP36.pdf page 2(accessed 12 February 2014).

${ }_{19}$ Birch Ibid fn 2 at 145.

20 A Wing, "The South African constitution as a model for the United States," 24(2008) Harvard Black Letter Law Journal 73-80 at 74.

21 Y Mokgoro, "Ubutu and the law in South Africa," paper presented at the first colloquium constitution held at Potchefstroom on 31 October 1997 at 3. Also see T Bennett, "Ubuntu: An African equity," 14:4(2011) Potschefstroom Electronic Law Journal. Available at http://www.ajol.info/index.php/pelj/article/view/68745/56815 (accessed 10 April 2013).

22 I Buccus, "Civil society and participatory policy making in South Africa: Gaps and opportunities," paper presented at the Democracy Development Programme Workshop, 7-8 September 2009, Durban, http://www.ddp.org.za at 4 (accessed 8 December 2012).
} 


\section{A Synopsis of Pre-2010 Legislative Law-Making in Kenya}

In 1964, Kenya became a Republic under Constitution of Kenya (Amendment) Act 28 of 1964. A presidential system of government was preferred to the then existing parliamentary one due to what was argued as the need to "establish and maintain stability and order."23The problems associated with a conventional presidential system as described by Linz became true of Kenya with the advent of its republican status. Linz argues that such a system vests the president, as the chief executive, with full authority and powers and he also doubles as the symbolic head of state. ${ }^{24}$ The two main strands of presidentialism are to plebiscitarian legitimacy and the fixed term of office which he or she enjoys. ${ }^{25}$ Linz also argues that presidential constitutions also reflect substantial suspicion of personification of power perhaps due to the "winnertake-all arrangement which makes politics a zero-sum game".

In addition and as Goulbourne has observed, sheer incumbency generates immense authority of a president. Other scholars have argued that presidential power is difficult to restrain and there is a strong likelihood that presidents may indeed sabotage institutions intended to check their power. ${ }^{26}$ The system may tilt towards dictatorship and tyranny mainly due to insufficient constitutional restraint which enhances presidential authority. These observations seem apposite with regards to Kenya's experience with presidential democracy whose 'big-man'leadership was manifested in the centralisation and unrestrained presidential power for most of the country's democratic experience. It is on this conceptual basis that the state of the country's legislative law making under the 1963 Constitution is briefly examined.

At Kenya's independence, the main pre-occupation of Jomo Kenyatta's ruling party, the Kenya African National Union (KANU) was "power transfer."27 KANU did not conceal its displeasure with decentralisation of power. For this reason, they embraced constitutional 'reforms' which could only be implemented through a robust law making process under an executive compliant legislature. The take-off point in the scheme of weakening the legislature and consequently its main function of law-making was the destruction of competitive politics enshrined in the Constitution. This was orchestrated mainly by destabilising the Kenya National Democratic Union (KADU) through intimidation and promises for cabinet appointments if they joined KANU.KADU succumbed to the pressure, dissolved itself joined KANU and its leaders, Ronald Ngala, Daniel arap Moi and Masinde Muliro were appointed to the cabinet. ${ }^{28}$ This made Kenya a de facto one-party state which we view to have been the cornerstone for the emasculation of the legislature by the executive. It also severely eroded the credibility of the legislature as an independent law making body and indeed became the key machinery for perpetrating the oligarchy of the executive in the country.

Unbridled dissipation of electoral democracy and separation of powers became more apparent when Daniel arap Moi took over power in 1978 following the death of Jomo Kenyatta. Parliament and its entire law making process became the main strategy applied by the Executive, for instance Constitution of Kenya (Amendment) Act 7 of 1982 which made KANU the country's de jure political party. The effect of the amendment was that it vested the entire electoral democratic process under the president's control which was enhanced by section 41(1) of the Constitution which empowered the president to appoint all members of the Electoral Commission. Under the circumstances, his statement that KANU was supreme over Parliament, and the courts, was not shocking. ${ }^{29}$ Dismaying to any jurist as this view may seem, it was buttressed by the statement of Attorney-General Amos Wako when he told Parliament in 1991 that "a characteristic of the rule of law is that no man, save for the president, is above the law."30

Although plural democracy was restored by Constitution of Kenya (Amendment) Act No 12 of 1991, the law making process remained under the yoke of the executive until 2002 when the opposition coalition, the National Rainbow Coalition (NARC) trounced KANU. ${ }^{31}$ Wrangles within the NARC coalition were the major barrier to constitutional reforms which hopefully could have reshaped the country's law-making process. Reforms promised in 2002 became a reality in 2010 when a new constitution was promulgated, the process of which commenced in earnest after the 2007 post-election violence which nearly shoved the country "on the brink of the precipice." 32 We now turn to the plight of law making under

\footnotetext{
23 Y Ghai \& J Mcauslan, Public law and political change in Kenya: A study of the legal framework of government from the Colonial Times to the Present Day, (1970) at 220.

24 J Linz, "The perils of presidentialism," 1:1 (1990) Journal of Democracy 51-69 at 52.

25 Linz lbid at 53

26 S Rose-Ackerman et al, "Leveraging presidential power: Separation of powers without checks and balances in Argentina and the Philippines," Yale Law School Faculty Scholarships Series (2010) at 1

27 H Okoth-Ogendo, "The politics of constitutional change in Kenya since independence, 1963-1967" 71: 282 (1972) African Affairs 9-34 at 13.

${ }_{28}$ C Odiambo-Mbai, "The rise and fall of the autocratic state in Kenya," in W Oyugi et al, The politics of transition in Kenya, Henrich Bòll Foundation (2003) at 60.

${ }^{29}$ G Murunga, "The state, its reforms and the question of legitimacy in Kenya," 5:1\&2 (2004) Identity, Culture and Politics 179-206 at 191.

${ }^{30}$ M Mutua, "Justice under siege: The rule of law and judicial subservience in Kenya," 23 (2001) Human Rights Quarterly 96-118 at 100 For a thorough discussion of the role of the Attorney-General, see C Goredema, "The Attorney General in Zimbabwe and South Africa: Whose weapon? Whose shield?" (1997) Stellenbosch Law Review 45-64; also see G Musila "The office of the Attorney General in East Africa: Protecting public interest through independent prosecution and quality legal advice," (2013)South African institute for advanced constitutional, public, human rights and international law (SAIFAC) http://www/saifac.org.za/docs/res_papers/ RPS\%20NO.\%2013.pdf (accessed 22 May 2013).

${ }^{31}$ For a thorough exploration of the infighting within the NARC coalition, see G Murunga \& S Nyasong'o, "Bent on self-destruction: The Kibaki regime in Kenya," $24: 1$ Journal of Contemporary African Studies 1-28 (2006)

32 See, Kenya National Commission of Human Rights, "On the brink of the precipice: A human rights account of Kenya's post 2007 election violence."
} 
the new democratic dispensation.

\section{Law-Making by the Legislature under the New Dispensation}

After the 2007 post-election violence came to an end through the African Union initiative spearheaded by Kofi Anan, the Commission of Inquiry on Post-Election Violence (CIPEV) was formed so as to investigate the causes of the violence and to make the necessary recommendations. The main recommendation by CIPEV chaired by Court of Appeal Judge Phillip Waki, was the need for fundamental constitutional and legal reforms so as to address impunity, the bedrock of the country's discoloured governance record. ${ }^{33}$

The foregoing recommendation was the genesis of the 2010 constitution-making process. With the benefit of hindsight, the 2007 post-election violence could perhaps have been avoided had the NARC government committed itself to genuine constitutional reforms as promised on its road to dislodging KANU from power. The key legislation for constitutional review passed under Anan's reconciliation vehicle, the Kenya National Dialogue and Reconciliation (KNDR), was the Constitution of Kenya Review Act 9 of 2008 (The 'Review Act'). Our submission is that the Review Act was the law upon which full participation of the people in legislative law making as enshrined in the 2010 Constitution lawmaking was anchored.

A close scrutiny of the Review Act demonstrates a clear intention to reposition the country's Westminster puritarian representative democracy to a hybrid system of representative and direct democracy. The intention was to tackle the massive failures of a pure representative system. Among other aims, section 4 of the Act stated that the constitutional review exercise was intended to secure provisions for ensuring the full participation of people in the management of public affairs.

With a view to adopting the shift in the law-making process as envisaged in the Review Act, the Constitution has key provisions which espouse the philosophy of direct participation of the people in the management of public affairs and law-making in particular. The Constitution proclaims that "the legislative authority of the Republic is derived from the people and, at the national level, is vested in and exercised by Parliament." ${ }^{34}$ Membership of the National Assembly and the Senate which both constitute Parliament manifest the spirit of the reforms contemplated in the Review Act.

Among the members of the National Assembly are forty-seven women, each elected by the registered voters of the counties, each constituting a single member constituency ${ }^{35}$ and twelve members nominated by parliamentary political parties according to their proportion of members of the National Assembly to represent special interests, including the youth, persons with disabilities and workers. ${ }^{36}$ On the Senate, its membership include sixteen women who shall be nominated by the registered voters of the counties, each county constituting a single member constituency; ${ }^{37}$ two members, being one man and one woman, representing the youth ${ }^{38}$ and two members being one man and one woman, representing persons with disabilities. ${ }^{39}$ The appointment of representatives of the foregoing groups is solidified by Article 100 of the Constitution which provides for the enactment of legislation for that purpose.

Further, and more central to our discussion, Article 118 (1)(b) provides that Parliament should facilitate public participation and involvement in the legislative and other business of Parliament and its committees. In strengthening the spirit of popular engagement in the affairs of state, Article 119(1) provides that Parliament may be petitioned by any person to enact, amend or repeal any legislation. In this regard, Article 119(2) directs Parliament to make provision for the procedure for the exercise of that right.

The ideal of public participation in legislative business of Parliament is replicated in the Counties. Article 196(1) (b) provides that a county assembly shall 'facilitate public participation and involvement in the legislative and other business of the assembly and its committees'. This provision reinforces the philosophy of full participation of the people in the management of public affairs as effectively captured in the Review Act. This is also one of the ways in which the sovereign power of the people is exercised. ${ }^{40}$

\footnotetext{
${ }^{33}$ Report of the Commission of Inquiry into Post-Election Violence 2008 at 480.

${ }^{34}$ Article 94 (1).

35 Article 97 (1)(b).

${ }^{36}$ Article 97 (c).

${ }^{37}$ Article 98 (b).

38 Article 98 (c).

${ }^{39}$ Article 98 (d).

${ }^{40}$ Article 1(4) (b).
} 


\section{Disjuncture in Kenya's New Law-Making Process}

\subsection{Public Participation in Law-Making}

This part of the article examines the extent to which the constitutional concept of public involvement has been embraced as envisaged in the Review Act. The most imperative process towards the realisation of the intent and spirit of the 2010 Constitution is an effective implementation of the Constitution. In this regard, the Commission for the Implementation of the Constitution (CIC) is established as a transitional commission in terms of Article 262 and section 5(1) of the Sixth Schedule of the Constitution and the Commission for the Implementation of the Constitution Act 9 of 2010. Some comments made by the $\mathrm{CIC}$ on legislative law-making process will shed some light on the degree of Parliament's commitment to engage the people in its legislative agenda.

In the discharge of its constitutional obligations, the $\mathrm{CIC}$ has come across major obstacles in its endeavour to see the engagement of the people in legislative business. In its Third Quarterly Report for 2011, the CIC discloses a lawmaking process which at the national level divests those laws of any validity. Further, it is a pointer to the need for more vigilance in the law-making process so as to consolidate the democratic gains evident under the new dispensation as we avoid the pitfalls of the past.

The $\mathrm{CIC}$ report mentioned above enumerates examples of "blatant violation of the Constitution." ${ }^{11}$ Examples include: the unconstitutional enactment of the Contingencies Fund and County Emergency Funds Act, 2011 and the National Government Loans Guarantee Act 2011 as the CIC was not involved; 42introduction of amendments of Bills approved by the $\mathrm{CIC}$, for instance the important Commission on Revenue Allocation Bill 2011, thus Parliament circumventing $\mathrm{ClC}$ scrutiny of the Bills which is worsened by the Executive's ignorance of $\mathrm{ClC}$ advisories in this regard. ${ }^{43}$

Other key violations of the Constitution for the period under CIC's review included the grave sin of disregarding the participation of the people in law making; ${ }^{44}$ a complete refusal of Parliament and the Executive of High Court order to stop the passage into law of the Government Loans Guarantee and the Contingencies Fund and County Emergency Bills for being unconstitutional. ${ }^{45} \mathrm{To}$ add to the long list of Bills passed by Parliament in utter violation of the requirement for the participation of the people are changes to the Political Parties Act 2011. In June 2012, MPs, without public participation, passed crucial amendments to the Act so as to permit floor-crossing without losing their seats in Parliament. Calls by the chairperson of the CIC, and some MPS that the Bill was unconstitutional went unheeded. ${ }^{46}$

The most important instrument which regulates the business of Parliament is the Standing Orders. It is in this instrument where clear procedures and entrenchment of public participation as envisioned in the Review Act and in the Constitution should be found. This is more so because the new Standing Orders of the National Assembly were adopted in January 2013, almost three years into the new Constitution. The Standing Orders provide that "the Departmental Committee to which a Bill is committed shall facilitate public participation and shall take into account the views and recommendations of the public when the committee makes its report to the House." 47

The foregoing provision causes unease because the entire process, mechanism and operation of the cardinal principle of public participation is at the discretion of a Committee of the House. The National Assembly has not in its Standing Orders created safeguards to ensure that the views of the people who make presentations to the Committee are taken on board and given due consideration. The situation becomes more disturbing when allegations of corruption among committee members are made by none other than the Deputy Minority Leader of the National Assembly. ${ }^{48}$ In addition, complaints against incompetence of committees were recently made by the Majority Leader of the National Assembly who called upon the Speaker of the House to 'reign in chairmen who have not understood their roles as the leadership of the committees...'49

It is now appropriate to investigate whether the other chamber of Parliament, the Senate, has a different approach to public participation in its business. According to the Constitution, one of the roles of the Senate is to protect the interests of the county governments which are established to ensure the success of devolution. ${ }^{50}$ In this regard, one would expect to see clear guidelines in the Standing Orders of the Senate on how the people from various counties would

\footnotetext{
${ }^{41}$ Commission for the Implementation of the Constitution (CIC): "Third quarterly report: July-September 2011," at 4.

42 CIC Ibid at 15

${ }^{43} \mathrm{CIC}$ lbid at 51-52 and 32-33.

${ }^{44} \mathrm{ClC}$ lbid at 52

45 CIC Ibid at 32

46 Daily Nation, "Kenyan MPs can now defect at will. Available at http://www.nation.co.ke p1. (Accessed 22 June 2012).

${ }^{47}$ Standing Order 127(3).

${ }^{48}$ Daily Nation, 'Corruption in House Worries MPs', http://.nation.co.ke/news/Corruption-in-House-worries-MPs/... 18 March 2014. Accessed 18 March 2014).

${ }^{49}$ Daily Nation, ibid.

${ }^{50}$ Article 96(1)(3).
} 
be engaged in the legislative function of the Senate. On the contrary, this is not the case.

The Standing Orders replicate those of the National Assembly by entrusting the procedure and consideration of the views of the public to a committee to which a Bill is committed. ${ }^{51} \mathrm{It}$ is also worth noting that in both Houses of Parliament, the Standing Orders have no provision on engaging the people on the amendment of Bills. The import of this is that a Bill might be fundamentally amended on the floor of the House without taking on board the views of the people on such amendment.

A County Assembly exercises legislative authority of a county. ${ }^{52}$ The assembly is one of the State organs in which the sovereign power of the people of Kenya is delegated by the Constitution. ${ }^{53}$ Proceedings of a county assembly shall be open to the public and shall facilitate public participation and involvement in its legislative and other business and in the business of its committees. County assemblies have merely replicated the approach of both Houses of Parliament which fail to create adequate mechanisms for the ideal of public participation in law-making to be fully entrenched in the country's legislative organs.

As an example, the Standing Orders of the Nairobi City County Assembly provides that the Sectoral Committee considering a Bill 'shall facilitate public participation and shall take into account the views and recommendations of the public when the Committee makes its report to the County Assembly'. It is therefore apparent that legislative law-making at national and county level is not underpinned by processes which unequivocally promote the right of the people of Kenya to participate in legislative law-making and related business.

\subsection{CIC's technique of "stakeholders-approach" to law-making}

As Sachs J., aptly observed in the landmark South African case of Doctors for Life v Speaker of the National Assembly and Others ${ }^{54}$, involvement of the people in law-making is a manifestation of respect for the people "as concerned citizens and legislators must have the benefit of all inputs that will enable them to produce the best possible laws." ${ }^{\text {"As }} \mathrm{As}$ examined above, the $\mathrm{CIC}$ has made several observations on the unconstitutional conduct of the Executive and Parliament in the law-making process. One of such accusations which indeed affects the legitimacy and validity of laws passed under the new Constitution is that in many cases, the people were not engaged in law-making or in its amendment.

The approach of the CIC to achieve the constitutional threshold of participation of the people of Kenya in lawmaking raises a degree of consternation and sets a dangerous precedent for future law-making. This is because the $\mathrm{CIC}$ violates the pragmatic meaning of popular sovereignty in law-making, the living spirit of the Constitution and the Review Act.

In its Report expounded above, the CIC's main approach is "interaction with stakeholders." It is argued that the implication of this flawed process is that public participation, what the Constitution demands, is being violated. The Report fails to indicate the parts of the country visited and the engagement with the people at grassroots level, in towns, villages and markets so as to obtain their views on various proposed laws. A few statements of the Report will authenticate, it is argued, the view that the $\mathrm{CIC}$ is more inclined to a stakeholder approach in contrast with the constitutionally envisaged and broader participation of the people.

On the Kenya Citizenship and Immigration Bill 2011 and the Kenya Citizens and Foreign Nationals Management Service Bill 2011, the CIC notes that involvement with key stakeholders resulted in "consensus on most of the provisions of the Bills was achieved in a shorter period of time." ${ }^{156}$ The same approach was replicated in the Ratification of Treaties Bill 2011. The CIC held consultations with stakeholders on the Bill after which the Bill "was forwarded to the office of the AG for final technical editing before transmission to the Cabinet for its deliberations." ${ }^{57}$ As for the Labour Relations Bill 2011, the CIC organised a "stakeholders' forum" which was "followed by a technical drafting session..." ${ }^{58}$ As regards public participation, the CIC Report notes that it "is critical to facilitate active participation by the different actors to ensure that the Bills submitted to $\mathrm{ClC}$ meet the threshold of consultation required under the Constitution." 59

The stakeholder approach adopted by the CIC should be part of the larger constitutional scheme and intent of fully engaging the people in law-making. It is therefore evident that the $\mathrm{CIC}$ has not fully adhered to the letter and spirit of the Constitution. The irony is that while the CIC attacks Parliament and the executive for violating the Constitution, it is

\footnotetext{
51 Standing Order 128(4).

${ }^{52}$ Article $185(1)$ of the Constitution.

${ }^{53}$ Article 1(3)(a).

${ }^{54}$ Doctors for Life International v Speaker of the National Assembly and Others 2006 (6) SA 416 (CC)

55 Ibid para 235.

${ }^{56} \mathrm{CIC}$ (fn 41above) at 23-24.

$57 \mathrm{ClC}$ lbid at 2

${ }_{58} \mathrm{CIC}$ lbid at 35

$59 \mathrm{ClC}$ Ibid at 54.
} 
equally guilty of breaching the supreme law and the cardinal ideal of participatory democracy.

\section{Conclusion}

This article has examined the ideal of popular participation with specific reference to law-making and its application to Kenya. It has been seen that participation of the people is a cardinal pillar of democracy as enshrined in key international and human rights instruments for instance the UDHR and the ICCPR and the ACHPR. From a Kenyan perspective, it has been argued that at independence, the country adopted a Westminster democratic system in which the legislature was intended to fulfil its rightful role under the doctrine of separation of powers. However, after Kenya became a Republic in 1964, constitutional amendments were passed by Parliament which unarguably destroyed the architecture of the 1963 Constitution. Of crucial importance was the 1982 amendment which made the country a de jure one party state. Although multi-partyism was later restored, Parliament continued to be an appendage of the executive thus denying the people through their representatives the fundamental role of meaningful contribution to law-making.

The article has argued that the country's constitutional reform initiatives which culminated in the 2010 Constitution were anchored on the need to enable the people of Kenya to directly participate in the affairs of state especially in lawmaking processes. The aim was to forestall the furtherance of a governance style which for decades relegated the people to mere spectators of public affairs and replaced it with a people-centric governance trajectory. The main challenge to this clear shift in the law-making process is that the country's political institutions which are central to the law-making process have intentionally neglected to meaningfully embrace the noble ideal of direct participation of the people in law-making.

In order to enjoy the full benefits envisaged in Kenya's constitutional reforms, legislation should be passed for the appropriate enablement of the Constitution because it does not stipulate the modalities for the direct participation of the people in law-making. Without such a clear approach, Parliament, county assemblies, the $\mathrm{CIC}$ and other institutions which at a national level have a central role to play in law-making will continue unabated to disregard the role of the people in law-making which counters the intent and spirit of the 2010 Constitution. It is also suggested that the people should be educated on their role in law-making and this may lead to judicial challenges of unconstitutional legislation which could be the take-off point for a truly entrenched popular democracy and jurisprudence in the country, a major step in tackling tyrannical and authoritarian governance.

\section{Acknowledgement}

This article is partially a version of a LLD thesis by John Mukuna titled "Political governance and constitution-making in Kenya: In search of popular participation" (unpublished) submitted for examination at the North West University (Mafikeng Campus) in November 2012.

\section{References}

Afro-barometer Network: Working Paper No.16, "Citizens and the state in Africa: New results from Afro-barometer round 3," $2005-2006$. Bennett, T "Ubuntu: An African equity" (2001) Potschefstroom Electronic Law Journal at 30-61.

Birch, A The concepts and theories of modern democracy $3^{\text {rd }}$ ed London: Routledge (2007).

Buccus, I "Civil society and participatory policy making in South Africa: Gaps and opportunities" (2009), Paper presented at the democracy development programme workshop, 7-8 September 2009, Durban.

Commission for the Implementation of the Constitution (CIC): First Quarter Report January-March 2013.

Commission for the Implementation of the Constitution (CIC): Third Quarterly Report: July-September 2011.

Constitutive Act of the African Union, http://www.africa-union.org/root/au/aboutau/constitutive_act_en.htm, (accessed 29 July 2013).

Ghai, Y \& McAuslan, J Public law and political change in Kenya: A study of the legal framework of government from the colonial times to the present day London: Oxford University Press (1970).

Goredema, C "The Attorney General in Zimbabwe and South Africa: Whose weapon? Whose shield?" (1997) Stellenbosch Law Review 45-64.

International Covenant on Civil and Political Rights, G.A. res. 2200A (XXI), 21 U.N. GAOR SUPP. (No.16) at 52, U. N. Doc.A/6316 (1966), 999 U.N.T.S. 171, entered into force Mar. 23, 1976, http://www1.umn.edu/humanrts/instree/b3ccpr.htm accessed 12 June 2013.

Linz, J "The perils of presidentialism," (1990) Journal of Democracy 51-69.

Hatchard, J., Ndulo, M \& Slinn, P Comparative Constitutionalism and Good Governance in the Commonwealth (2011)

Madison, $\mathrm{J}$ "The alleged tendency of the new plan to elevate the few at the expense of the many considered in connection with representation" The Federalist No. 57, http://www.constitution.org/fed/federa57.htm .Accessed 10 March 2013.

Madison J, "The Senate" The Federalist No. 62, http://www.constitution.org/fed/federa62.htm. Accessed 19 April 2013. 
Madison, $\mathrm{J}$ "The utility of the union as a safeguard against domestic faction and insurrection" The Federalist No. 10http://www.constitution.org/fed/federa10.htm .Accessed 8 June 2013.

Mbao, M \& Komboni, G "Promotion of good Governance and combating corruption and maladministration: The case of Botswana," (2008) Law, Democracy and Development Journal, University of the Western Cape 49-71.

Mokgoro, J "Ubuntu and the law in South Africa" (1997), Paper presented at the first colloquium constitution held at Potchefstroom, 31 October 1997.

Murunga, G \& Nasong'o S "Bent on self-destruction: The Kibaki regime in Kenya," (2006) Journal of Contemporary African Studies1-28.

Murunga, G "The state, Its reform and the question of legitimacy in Kenya," Identity, Culture and Politics (2004)179-206.

Musila, G "The office of the Attorney General in East Africa: Protecting public interest through independent prosecution and quality legal advice" (2013)South African institute for advanced constitutional, public, human rights and international law (SAIFAC) http://www/saifac.org.za/docs/res_papers/RPS\%20NO.\%2013.pdf .Accessed 22 May 2013.

Mutua, M "Justice under siege: The rule of law and judicial subservience in Kenya," (2001) Human Rights Quarterly 96-118.

Ochoa, C "Participatory democracy and law formation," (2008) Indian Journal of Global Legal Studies5-18.

Odhiambo-Mbai, C "The rise and fall of the autocratic state in Kenya," in Wanyande P, Oyugi, W \& Odhiambo-Mbai C The Politics of transition in Kenya: From KANU to NARC Nairobi: Heinrich Bòll Foundation: English Press Ltd (2003)51-59.

Okoth-Ogendo, $H$ "The politics of constitutional change in Kenya since independence, 1963-69," (1972) African Affairs 9-34.

Osmani, S "Participatory governance: An overview and evidence," United Nations department of economic and social affairs: New York (2008). http://www.unpan1.un.org/intradoc/groups/public/.../un/unpan028359.pdf .Accessed 9 June 2013.

Quandt, M "In defence of participatory democracy" http://www.nicanet.org/wp-content/.../158-/participatorydemocracy-b.pdf. Accessed 9 February 2013.

Report of the Kenyan Commission of Inquiry into Post-Election Violence (2008).

Simutanyi, N "Parties in parliament: The relationship between members of parliament and their parties in Zambia" (2005)EISA occasional paper Number 36," (2005), http://www.eisa.org.za/PDF/DF/OP36.pdf page 2. Accessed 8 May 2012. 